\title{
Distribution and Diversity of Oligochaetes in Selected Ponds of Thiruvananthapuram District, Kerala, South India
}

\author{
M. S. Ragi and D. S. Jaya \\ Department of Environmental Sciences, University of Kerala, Kariavattom Campus, Thiruvananthapuram, Kerala 695 581, India \\ Correspondence should be addressed to M. S. Ragi; ragims369@gmail.com
}

Received 4 April 2014; Revised 19 June 2014; Accepted 30 June 2014; Published 17 July 2014

Academic Editor: Junbao Yu

Copyright (C) 2014 M. S. Ragi and D. S. Jaya. This is an open access article distributed under the Creative Commons Attribution License, which permits unrestricted use, distribution, and reproduction in any medium, provided the original work is properly cited.

The present study was carried out to evaluate the distribution and diversity of oligochaete fauna in selected ponds of Thiruvananthapuram district in Kerala, South India. The sediment samples were collected from three ponds seasonally during the period December 2006 to November 2008. In the study, 10 oligochaete species which belong to 8 genera were identified in three selected ponds. These include Dero digitata, Dero nivea, Dero obtusa, Pristina longiseta, Aulophorus furcatus, Stylaria fossularis, Chaetogaster spp., Aeolosoma spp., Tubifex tubifex and Limnodrilus hoffmeisteri. Tubifex tubifex and Limnodrilus hoffmeisteri are the pollution-indicator oligochaete species identified in the fresh water ponds, which reveals that the studied ponds are subjected to pollution.

\section{Introduction}

Oligochaetes, a subclass of Clitellata, in phylum Annelida, have a worldwide distribution and are the most abundant benthic organisms in many fresh water ecosystems [1]. Oligochaetes are used in biodiversity studies, pollution surveys, and environmental assessment and they have economic importance [2]. Oligochaetes in general have wide geographical distribution patterns [3] and their populations can sometime reach large numbers [1]. Many species prefer eutrophic waters and living on muddy sediments with abundant detrital organic matter [4].

The fauna of aquatic oligochaeta from India has been studied and identified by many scientists [5-14]. Among the main taxonomic groups present in the most benthic macro invertebrate communities, the oligochaetes are common and abundant, and some species are considered good bioindicators, particularly for the assessment of trophic state and organic pollution in water bodies [15].

The literature survey shows that the work performed by various authors on aquatic oligochaeta in water bodies of Kerala state, India, was meager. The major objective of the present study is to determine the diversity and distribution of oligochaeta fauna and its seasonal variations in three selected ponds of Thiruvananthapuram district, South India.

\section{Methods}

2.1. Study Area. The present study was carried out in three perennial ponds situated at different locations in Thiruvananthapuram District, Kerala state, the southern part of India (Figure 1). It include the temple pond (P1) situated near Rishimangalam temple and two public ponds, one situated in Muttacaud (P2) and the other one in Vilappilsala (P3). The period of study was from December 2006 to November 2008, in the postmonsoon (PM), premonsoon (PRM), and monsoon (MON) seasons.

Pond $1(\mathrm{P} 1)$ is situated in $8^{\circ} 29^{\prime} 46.07^{\prime \prime} \mathrm{N}$ latitude and $76^{\circ} 56^{\prime} 28.31^{\prime \prime} \mathrm{E}$ longitude, $1.5 \mathrm{~km}$ away from Thiruvananthapuram Central Railway station, and is in the premises of Rishimangalam temple, with an area of $1100 \mathrm{~m}^{2}$ and depth $226 \mathrm{~cm}$. Water in this pond is used for bathing and washing clothes. Also the wastes from nearby hospital and houses are usually dumped in the surroundings of this pond. Pond 2 (P2) is located in $8^{\circ} 24^{\prime} 5^{\prime \prime} \mathrm{N}$ latitude and $76^{\circ} 59^{\prime} 15^{\prime \prime} \mathrm{E}$ longitude, $13 \mathrm{~km}$ away from Thiruvananthapuram Central Railway station and covering an area of $1400 \mathrm{~m}^{2}$ and depth $230 \mathrm{~cm}$. Residents in the nearby areas use the pond water for irrigation, bathing, and other domestic purposes. Pond 3 (P3) is located in $8^{\circ} 31^{\prime} 15^{\prime \prime} \mathrm{N}$ latitude and $77^{\circ} 02^{\prime} 43^{\prime \prime} \mathrm{E}$ longitude, $19 \mathrm{~km}$ away from the Thiruvananthapuram Central Railway 


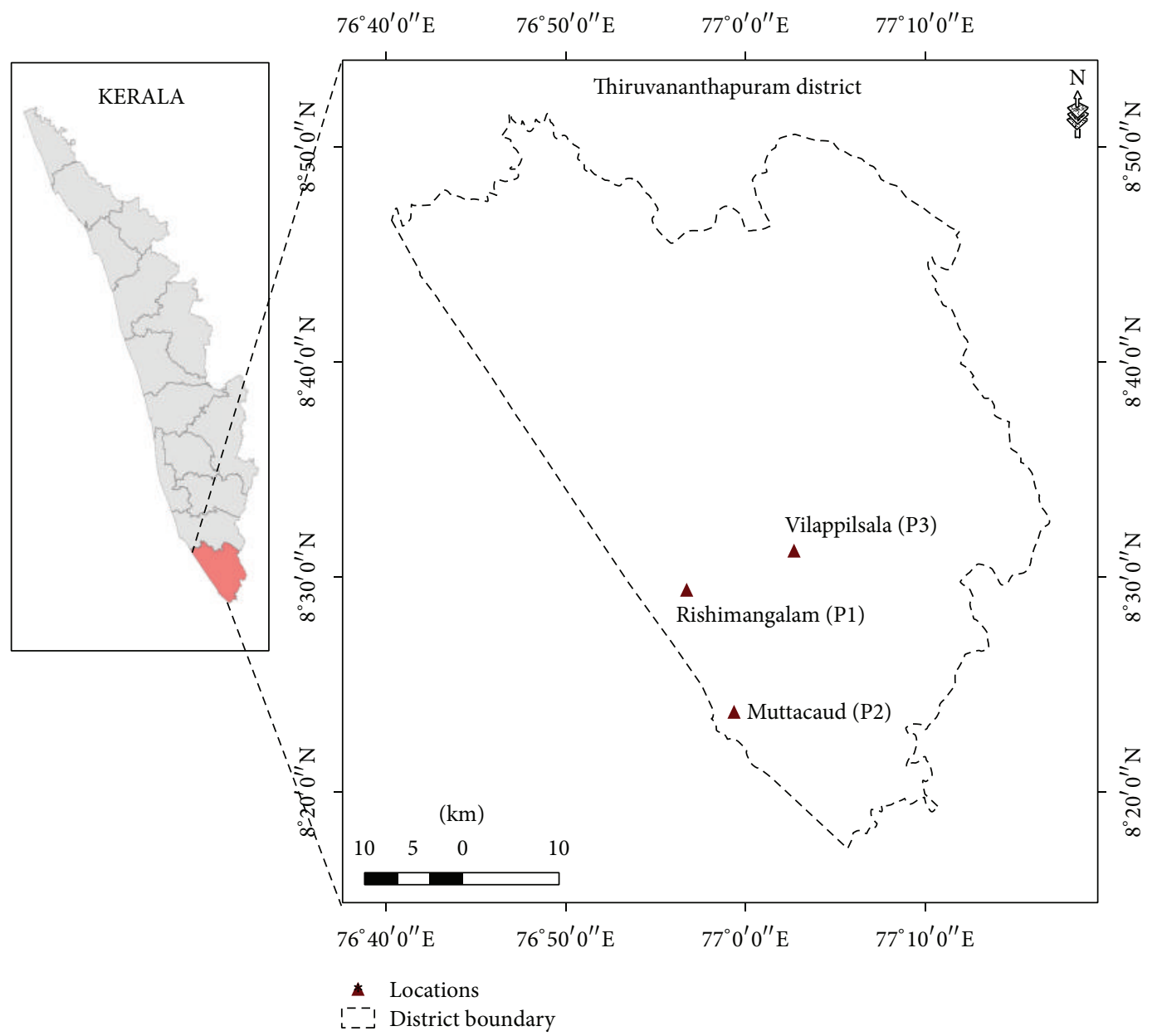

FIGURE 1: Map showing location of ponds in study area.

station and with an area of $1300 \mathrm{~m}^{2}$ and depth $218 \mathrm{~cm}$. This pond water is extensively used by public for irrigation, washing clothes, bathing, and cattle wash.

2.2. Methodology. Surface sediment samples were collected from four different sites of the selected ponds. Sampling was done between 6.00 am and $9.00 \mathrm{am}$. Sediment samples were collected with a PVC made tubular corer $(5 \mathrm{~cm}$ in diameter), inserted into the sediment at a depth of about $10 \mathrm{~cm}$. Four replicate sediment samples from each pond were also taken, and oligochaete distribution was studied. The samples were washed through a sieve of $0.2 \mathrm{~mm}$ mesh $(200 \mu \mathrm{m})$ in diameter, and the worms were sorted manually by diluting small portions of the sediment residue in a petri dish. A subsample of $100 \mathrm{~mL}$ was taken and oligochaetes were sorted out using a long dropper with the help of monocular ordinary dissection microscope (Olympus, Japan). Counting of oligochaetes was done using a Compound microscope (Olympus, Japan). All organisms were counted according to the procedure described by Welch [16]. With the help of a dissection microscope, the worms were picked with pincers and preserved in $10 \%$ formalin in separately labeled vials. The worms preserved in $10 \%$ formalin were cleared with a few drops of lactic acid. Photomicrographs of oligochaetes were taken using a compound microscope fitted with a digital camera. Drawings were made using a camera lucida and identification of oligochaeta to species/genus level was done according to the taxonomic criteria adopted by Brinkhurst [17] and Ward and Whipple [18].

The species diversity was calculated using the formula provided by Shannon and Weaver [19], which is as follows:

$$
\stackrel{s}{H_{i=1}^{\prime}}=-\Sigma P_{i} \ln P_{i}
$$

where

$H^{\prime}$ is the species diversity index.

$S$ is the number of species.

$P_{i}$ is the proportion of individuals of each species.

\section{Results}

3.1. Oligochaeta Identification. In this study, altogether 10 oligochaete species were identified, which include taxa with wide ecological tolerances. 


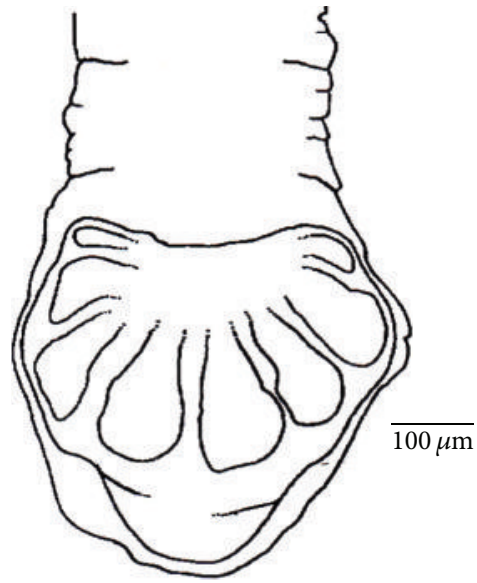

(a)

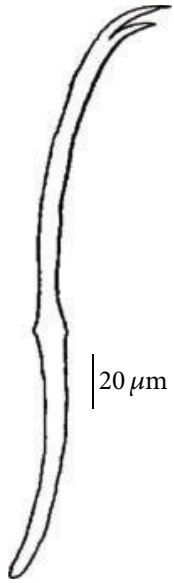

(b)

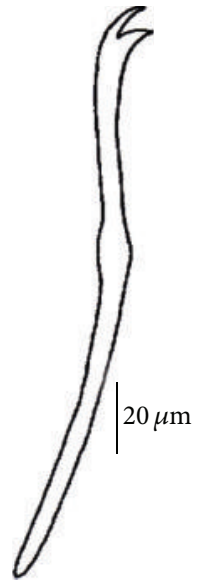

(c)

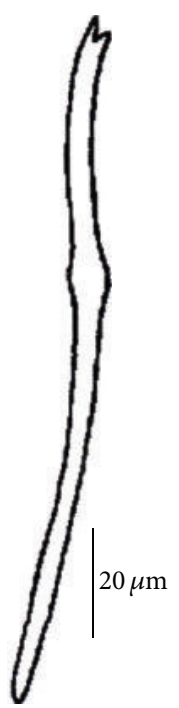

(d)

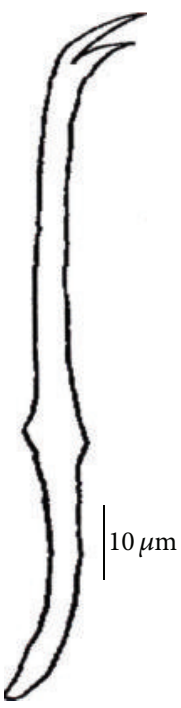

(e)

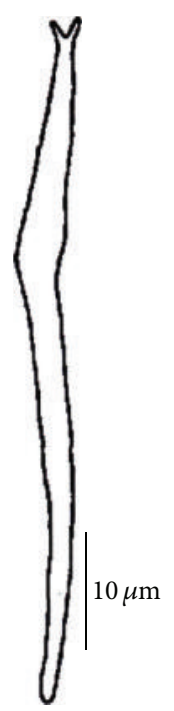

(f)

Figure 2: (a-d) Dero digitata: (a) posterior end, (b) ventral anterior chaetae, (c) ventral posterior chaetae, and (d) needle chaetae. (e-f) Dero nivea: (e) ventral chaetae and (f) needle chaetae.

Seven species from Naididae, two species from Tubificidae, and one species from Aeolosomatidae were identified from the studied ponds. The identified species include Tubifex tubifex Müller, 1774, Limnodrilus hoffmeisteri Claparede, 1862, Stylaria fossularis Linnaeus, 1967, Pristina longiseta Ehrenberg, 1828, Dero digitata Müller, 1774, Dero nivea Aiyer, 1929, Dero obtusa d'Udekem, 1885, Aulophorus furcatus Müller, 1773, Aeolosoma spp. Ehrenberg, 1828, and Chaetogaster spp. Von Baer, 1827.

\subsection{Taxonomical Description}

\section{Family: Naididae}

\section{(1) Dero Digitata Müller, 1774 (Figures 2(a)-2(d))}

Morphological Observations. D. digitata is one of the most common species of Naididae oligochaetes. It is an elongated, segmented worm, ranging in size from 6 to $32 \mathrm{~mm}$, and weighing around $0.06 \mathrm{mg}$. The anterior part is formed by five ventral chaetae bearing segments, plus a cone-shaped prostomium and small peristomium. It has no eyes. Dorsal bundles from VI, with 1 hair and 1 needle. The distal tooth of the needles are longer than the proximal. Ventral chaetae 4-5 in II-V with distal teeth are longer than the proximal. From VI onwards, ventral chaetae 2-4 with distal and proximal teeth are almost equal. Branchial fossa is with 4 pairs of gills. The presence of 1 hair and 1 needle in the dorsal bundle is a characteristic feature of this species. $D$. digitata is most likely a cosmopolitan species; it can be found in muddy deposit in ponds and sluggish bog streams.

\section{(2) Dero Nivea Aiyer, 1929 (Figures 2(e)-2(f))}

Morphological Observations. Worms consist of 34-37 segments. Body is yellowish to transparent in colour. Eyes are absent. Prostomium is short and conical; the branchial fossa prolonged posteriorly. Three pairs of gills are on posterior end (usually only 2 pairs seen, 3 rd is reduced). Dorsal chaetal bundles start in segment VI onwards, consisting of one smooth hair and one weakly curved bifid needle. Teeth of dorsal chaetae are of equal length. Ventral chaetae in segments II-V are different from those of the rest of segments, with the upper tooth twice being as long as the lower, while posteriorly the teeth are of about equal length and the lower teeth are slightly thicker, or the upper teeth are slightly shorter than the lower ones. Anterior ventral chaetae is of $65-84 \mu \mathrm{m}$ in length.

\section{(3) Dero obtusa d'Udekem, 1885}

Morphological Observations. Two ventral and one lateral pairs of gills. A single crochet in each dorsal bundle, with the teeth being equal in length, anterior ventral chaetae with extremely thin teeth, and posterior ventral chaetae with very short teeth.

(4) Aulophorus furcatus Müller, 1774 (Figures 3(e)-3(g) and $5(e))$

Morphological Observations. Prostomium is bluntly conical. Dorsal chaetae begin from $\mathrm{V}$ with 1 hair and 1 bifid needle chaetae. Ventral chaetae 3-5 per bundle exist; in anterior bundles, upper tooth are slightly longer, decreasing to 23 posteriorly. Branchial fossa is cup-shaped with a pair of noncontractile palps and 3 pairs of gills.

(5) Pristina Longiseta Ehrenberg, 1828 (Figures $3\left(a-c_{2}\right)$ and $5(c))$

Morphological Observations. The species is easily distinguished from the foregoing species by the possession of specially elongated long hair chaetae in segment III. 


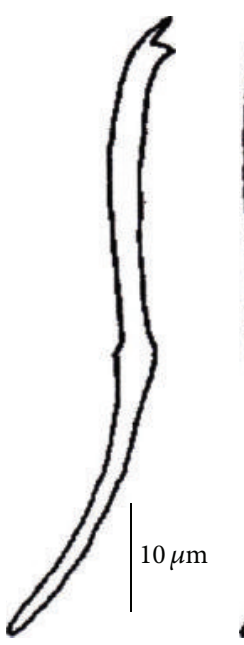

(a)

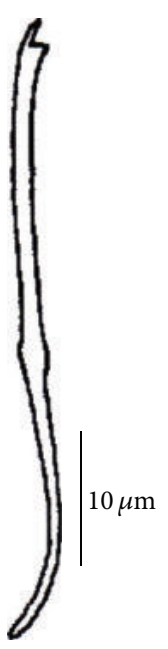

(b)

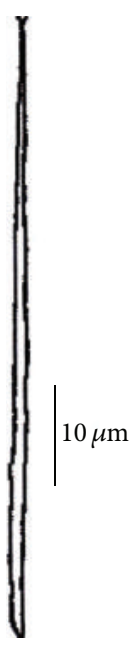

$\left(c_{1}\right)$

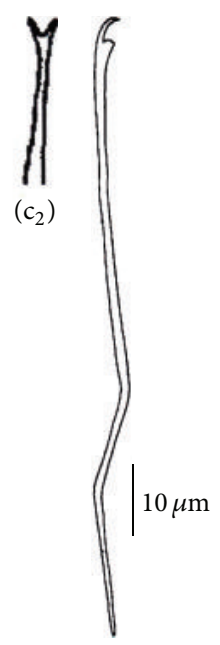

(d)

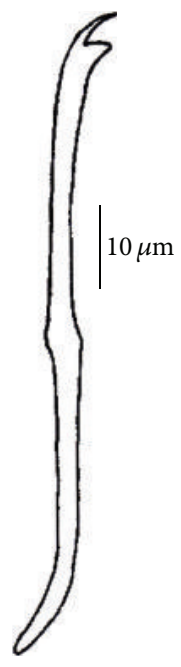

(e)

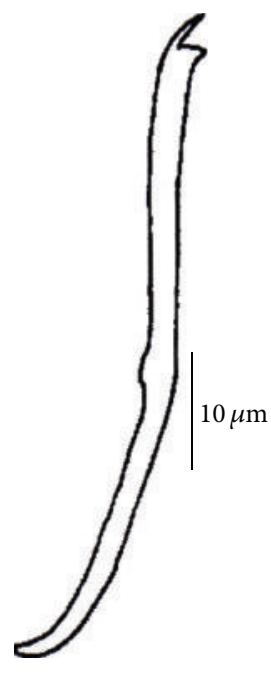

(f)

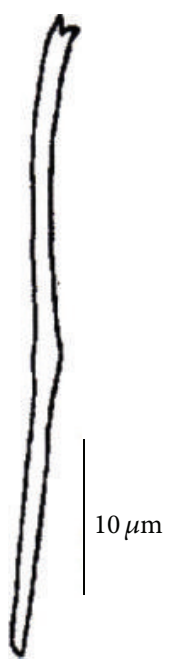

(g)

Figure 3: $\left(a-c_{2}\right)$ Pristina longiseta: (a) anterior ventral chaetae, (b) posterior ventral chaetae, $\left(c_{1}\right.$ and $\left.c_{2}\right)$ needle chaetae, and (d) Stylaria fossularis: ventral chaetae. (e-g) Aulophorus furcatus: (e) anterior ventral chaetae, (f) posterior ventral chaetae, and (g) needle chaetae.

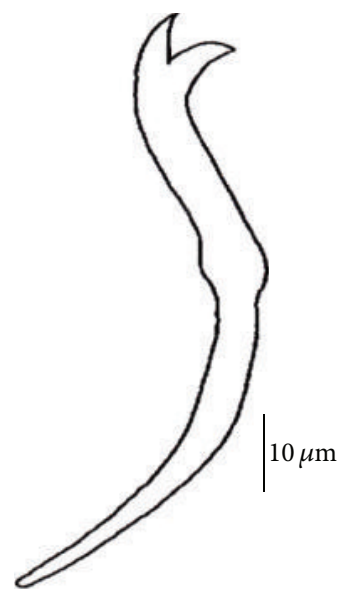

(a)

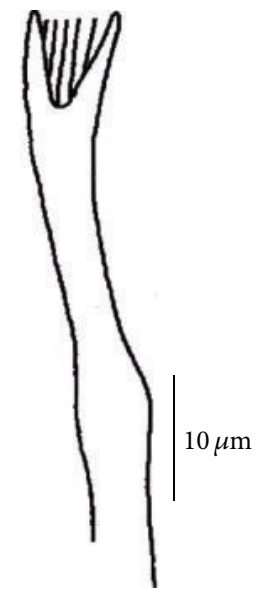

(b)

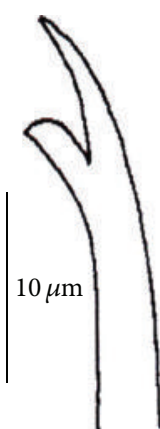

(c)

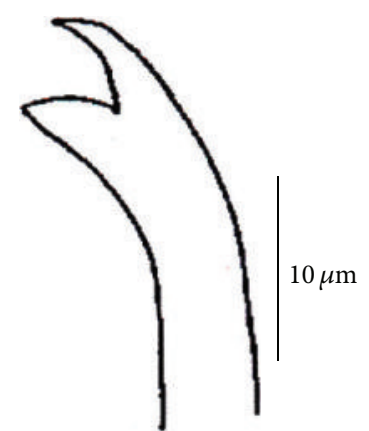

(d)

Figure 4: (a-b) Tubifex tubifex: (a) ventral chaetae and (b) pectinate chaetae. (c-d) Limnodrilus hoffmeisteri: (c) anterior ventral chaetae and (d) posterior ventral chaetae. 


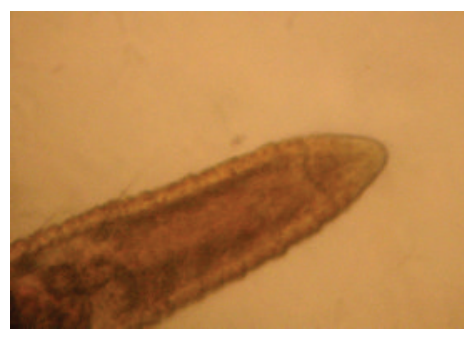

(a)

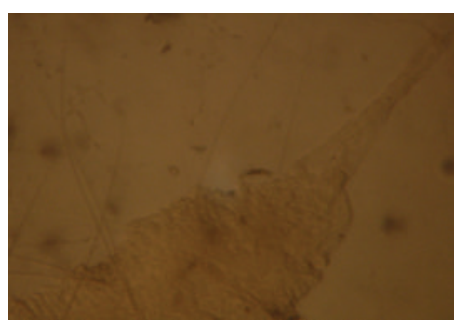

(d)

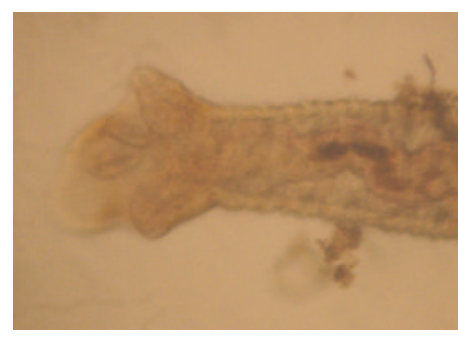

(b)

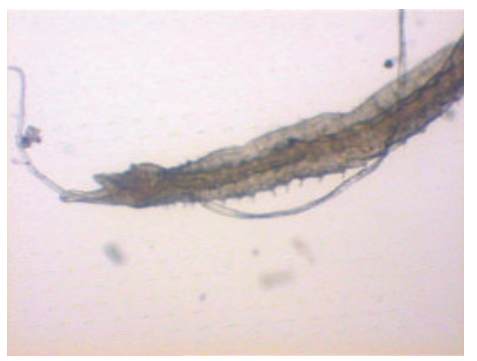

(e)

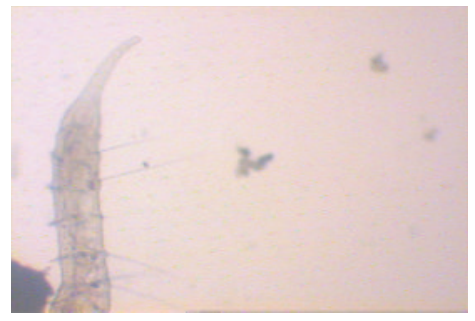

(c)

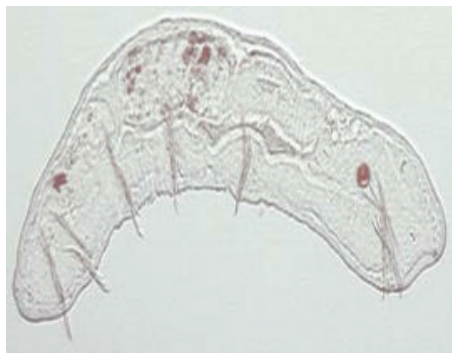

(f)

Figure 5: (a) Dero sp. anterior end, (b) Dero sp. posterior end, (c) Pristina sp. anterior end, (d) Stylaria fossularis. anterior end, (e) Aulophorus sp. posterior end, and (f) Chaetogaster sp. anterior end.

Dorsal crochets are simple pointed. Elongate hair chaetae on segment III exist. Ventral chaetae are simple bifid crochets with the upper tooth being thinner and a little longer than the lower.

\section{(6) Chaetogaster sp. Von Baer, 1827 (Figure 5(f))}

Morphological Observations. They are 2-25 mm long transparent worms that are very common in fresh water and often form chains of individuals through asexual multiplication. No dorsal chaetae exist. Ventral chaetae are present. Enlarged pharynx is observed.

\section{(7) Stylaria Fossularis Leidy, 1852 (Figure 3(d))}

Morphological Observations. Proboscis projects from the apex of the prostomium. Prostomium is not invaginated.

\section{Family: Aeolosomatidae}

\section{(8) Aeolosoma sp. Ehrenberg, 1828 (Figure 6(a))}

Morphological Observations. Hair chaetae exist in both dorsal and ventral bundles. Worms were less than $10 \mathrm{~mm}$ long. Prostomium is ciliated. Prominent oil droplets. Oil droplets are usually yellowish green in colour, frequently yellow, bluish green, and rarely brownish yellow. On the ventral surface of the prostomium the oil droplets are confined to the margin. Body is about $2-3.5 \mathrm{~mm}$ long in extended state. Prostomium is large, flat, and distinctly broader than the succeeding segments. It is very mobile. They are usually spherical in shape in cross-section. Chaetae exist in four bundles per segment; two dorsal and two ventral are beginning just behind the posterior end of the buccal funnel.

\section{Family: Tubificidae}

(9) Tubifex tubifex Müller, 1774 (Figures 4(a)-4(b) and 6(b)$6(c))$

Morphological Observations. Length was 20-30 mm. Segment number was $120-130$. Prostomium is bluntly conical. Dorsal bundles exist from II with hair and bifid chaetae. The dorsal bifid chaetae with distal tooth are thinner than proximal, simply bifid in II but pectinate in several subsequent segments, with small outgrowth (denticles) between teeth. Anterior ventral chaetae exist with thinner and longer distal tooth than proximal; the distal tooth is becoming shorter in both ventral and dorsal posterior segments. Tubifex tubifex, also called the sludge worm, or sewage worm, is a species of tubificid segmented worm that inhabits in the sediments of lakes and rivers on several continents. The worms can survive with little oxygen by waving their hemoglobin-rich tail ends to exploit all available oxygen and can exchange carbon dioxide and oxygen through their thin skins, in a manner similar to frogs.

(10) Limnodrilus hoffmeisteri Claparède, 1862 (Figures 4(c)$4(d)$ and $6(d))$

Morphological Observations. Limnodrilus hoffmeisteri is a small, thin worm about $20-35 \mathrm{~mm}$ in length. The worm appeared red in colour, owing to the possession of the respiratory pigment haemoglobin. Prostomium is conical. Dorsal and ventral chaetae commence from II segment, all bifid and similar, with distal tooth being thinner and equal in length with the proximal. Anterior segments bear 39 chaetae per bundle. The number of chaetae per bundle decreases in the succeeding segments, with about 3-5 in the middle segments and 1-2 in the most posterior segments. 


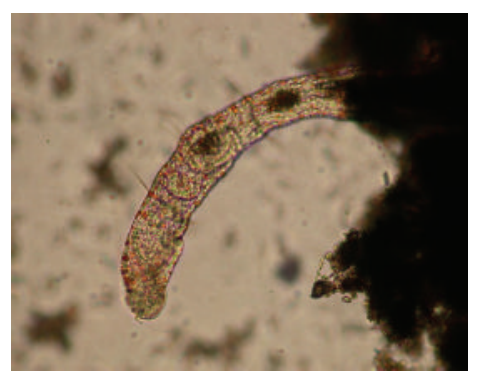

(a)

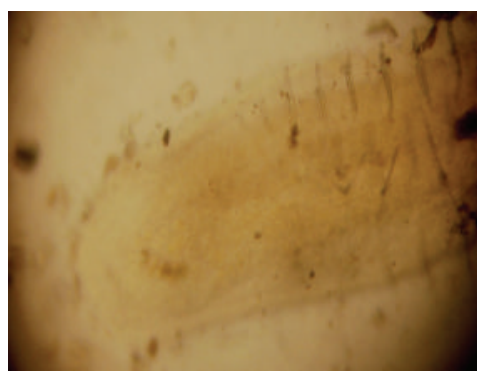

(c)

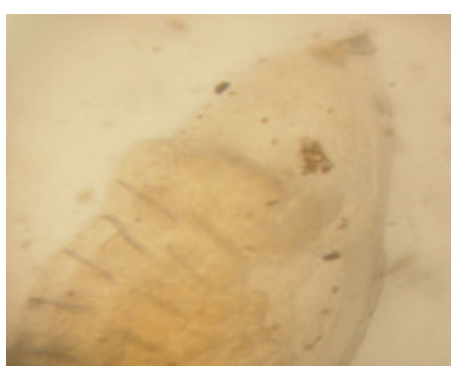

(b)

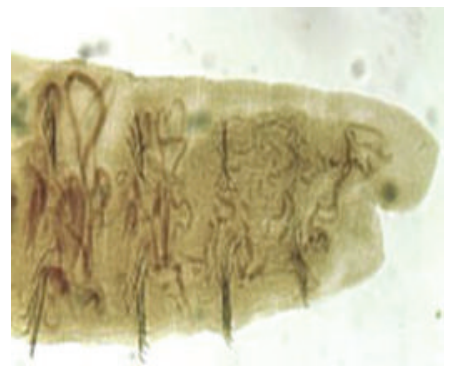

(d)

Figure 6: (a) Aeolosoma sp. anterior end, (b) Tubifex sp. anterior end, (c) Tubifex sp. posterior end, and (d) Limnodrilus sp. anterior end.

Clitellum occupies the XI and XII segments. The penis sheath is one of the diagnostic characters used in identification of these worms and can be very clearly seen through the transparent body surface. The penis sheath is much longer than broad (length-to-width ratio of about 9) and ends with an asymmetrical, plate-like extremity. Chloragogen tissue in this species starts from the $\mathrm{V}$ segment.

Seven species of oligochaetes were identified in pond 1 . These include Dero digitata, Dero nivea, Aulophorus furcatus, Pristina longiseta, Stylaria fossularis, Tubifex tubifex, and Limnodrilus hoffmeisteri. Of these, five species belong to Naididae family and two species belong to Tubificidae family.

In pond 2, eight taxons of oligochaetes were identified. These include Dero digitata, Dero nivea, Dero obtusa, Aulophorus furcatus, Chaetogaster spp., Stylaria fossularis, Aeolosoma spp.,and Tubifex tubifex. Six species are from Naididae family, one species from Aeolosomatidae, and one species from Tubificidae family.

In pond 3, seven species of oligochaetes were identified. These include Dero digitata, Dero obtusa, Aulophorus furcatus, Chaetogaster spp., Stylaria fossularis, Tubifex tubifex, and Limnodrilus hoffmeisteri. Five species belong to Naididae family and two species to Tubificidae family. It was also found that the population density of different oligochaete species in the studied ponds showed seasonal fluctuations. Limnodrilus hoffmeisteri was identified as a commercially exploited aquatic oligochaete species and was found in pond 1 and pond 3. But in pond 2, Tubifex tubifex was the only species identified in the Tubificidae family.

3.3. Population Density and Diversity of Oligochaetes. Density of oligochaetes (ind. $\mathrm{m}^{-3}$ ) in selected ponds during the periods of 2006-2007 and 2007-2008 is given in Tables 1 and 2, respectively. In Pond 1 Dero digitata, Dero nivea, Aulophorus furcatus, Pristina longiseta, Stylaria fossularis, Tubifex tubifex, and Limnodrilus hoffmeisteri were the oligochaete species identified during the study period. In Pond 2 Dero digitata, Dero nivea, Dero obtusa, Chaetogaster sp., Aulophorus furcatus, Stylaria fossularis, Aoelosoma sp., and Tubifex tubifex were identified during the study period. In Pond 3 Dero digitata, Dero obtusa, Chaetogaster sp., Aulophorus furcatus, Stylaria fossularis, Tubifex tubifex, and Limnodrilus hoffmeisteri were identified during the study period.

The highest density was recorded for Pristina longiseta (320 ind. $\mathrm{m}^{-3}$ ) in $\mathrm{P} 1$ during the postmonsoon season. In the second year of study (2007-2008) Pristina longiseta was found to be decreased (120 ind. $\mathrm{m}^{-3}$ ) at P1 during postmonsoon season. For Dero nivea at P2 (280 ind. $\mathrm{m}^{-3}$ ) the next highest population density was recorded during postmonsoon season. Aeolosoma genus was identified only in $\mathrm{P} 2$ and the highest value was 80 ind. $\mathrm{m}^{-3}$ and lower value was 40 ind. $\mathrm{m}^{-3}$. In P1 the density of pollution tolerant species, Tubifex tubifex, was maximum during postmonsoon season, in the second year of the study period (240 ind. $\mathrm{m}^{-3}$ ). Also lower density value (120 ind. $\mathrm{m}^{-3}$ ) was noted during the first year, monsoon season. In P2, density values of Tubifex tubifex were recorded to be highest during monsoon season (120 ind. $\mathrm{m}^{-3}$ ) and lower density value (40 ind. $\mathrm{m}^{-3}$ ) was recorded during the second year, in premonsoon season. In P3, highest density value for Tubifex tubifex was 240 ind. $\mathrm{m}^{-3}$. Limnodrilus hoffmeisteri was identified only at P1 and P3, and the highest density was obtained at P1 (160 ind. $\mathrm{m}^{-3}$ ) during premonsoon, and lowest density 
TABLE 1: Density of oligochaetes (ind. $\mathrm{m}^{-3}$ ) in selected ponds during the period 2006-2007.

\begin{tabular}{|c|c|c|c|c|c|c|c|c|c|}
\hline \multirow{2}{*}{ Species identified } & \multicolumn{3}{|c|}{$\mathrm{PM}$} & \multicolumn{3}{|c|}{ PRM } & \multicolumn{3}{|c|}{$\mathrm{MON}$} \\
\hline & $\mathrm{P} 1$ & $\mathrm{P} 2$ & P3 & $\mathrm{P} 1$ & $\mathrm{P} 2$ & P3 & $\mathrm{P} 1$ & $\mathrm{P} 2$ & P3 \\
\hline \multicolumn{10}{|c|}{ Naididae } \\
\hline Dero digitata & 160 & 120 & 160 & 200 & 160 & 120 & 160 & 240 & 160 \\
\hline Dero nivea & 200 & 280 & - & 160 & 160 & - & 120 & 200 & - \\
\hline Dero obtusa & - & 120 & 120 & - & 160 & 80 & - & 160 & 160 \\
\hline Chaetogaster spp. & - & 120 & 160 & - & 240 & 240 & - & 160 & 160 \\
\hline Aulophorus furcatus & 240 & 120 & 240 & 160 & 160 & 160 & 160 & 200 & 200 \\
\hline Pristina longiseta & 320 & - & - & 160 & - & - & 160 & - & - \\
\hline Stylaria fossularis & 160 & 160 & 160 & 120 & 80 & 120 & 120 & 120 & 160 \\
\hline \multicolumn{10}{|c|}{ Aeolosomatidae } \\
\hline Aeolosoma spp. & - & 80 & - & - & 40 & - & - & 80 & - \\
\hline \multicolumn{10}{|c|}{ Tubificidae } \\
\hline Tubifex tubifex & 200 & 80 & 240 & 160 & 80 & 160 & 120 & 120 & 120 \\
\hline Limnodrilus hoffmeisteri & 120 & - & 80 & 160 & - & 80 & 80 & - & 120 \\
\hline Total density & 1400 & 1080 & 1160 & 1120 & 1080 & 960 & 920 & 1280 & 1080 \\
\hline Species richness & 7 & 8 & 7 & 7 & 8 & 7 & 7 & 8 & 7 \\
\hline
\end{tabular}

TABLE 2: Density of oligochaetes (ind. $\mathrm{m}^{-3}$ ) in selected ponds during the period 2007-2008.

\begin{tabular}{|c|c|c|c|c|c|c|c|c|c|}
\hline \multirow{2}{*}{ Species identified } & \multicolumn{3}{|c|}{ PM } & \multicolumn{3}{|c|}{ PRM } & \multicolumn{3}{|c|}{ MON } \\
\hline & $\mathrm{P} 1$ & $\mathrm{P} 2$ & P3 & P1 & $\mathrm{P} 2$ & P3 & P1 & $\mathrm{P} 2$ & P3 \\
\hline \multicolumn{10}{|c|}{ Naididae } \\
\hline Dero digitata & 160 & 160 & 200 & 120 & 200 & 160 & 120 & 160 & 120 \\
\hline Dero nivea & 240 & 240 & - & 160 & 200 & - & 160 & 120 & - \\
\hline Dero obtusa & - & 120 & 160 & - & 80 & 120 & - & 120 & 200 \\
\hline Chaetogaster spp. & - & 160 & 120 & - & 120 & 160 & - & 200 & 160 \\
\hline Aulophorus furcatus & 160 & 240 & 160 & 200 & 120 & 200 & 160 & 160 & 160 \\
\hline Pristina longiseta & 120 & - & - & 120 & - & - & 160 & - & - \\
\hline Stylaria fossularis & 200 & 160 & 200 & 240 & 160 & 160 & 80 & 120 & 120 \\
\hline \multicolumn{10}{|c|}{ Aeolosomatidae } \\
\hline Aeolosoma spp. & - & 40 & - & - & 80 & - & - & 80 & - \\
\hline \multicolumn{10}{|c|}{ Tubificidae } \\
\hline Tubifex tubifex & 240 & 80 & 160 & 160 & 40 & 240 & 200 & 120 & 120 \\
\hline Limnodrilus hoffmeisteri & 40 & - & 80 & 80 & - & 40 & 120 & - & 80 \\
\hline Total density & 1160 & 1200 & 1080 & 1080 & 1000 & 1080 & 1000 & 1080 & 960 \\
\hline Species richness & 7 & 8 & 7 & 7 & 8 & 7 & 7 & 8 & 7 \\
\hline
\end{tabular}

value was obtained during postmonsoon (40 ind. $\mathrm{m}^{-3}$ ) season.

The Shannon-Weaver diversity index $\left(H^{\prime}\right)$ values for oligochaetes in the studied ponds in different seasons were calculated and are given in Table 3. In Pond 1 (P1), ShannonWeaver diversity index value for oligochaetes ranged from 1.85 to 1.94 . During the study period, the lowest diversity index value was noted in the postmonsoon season (1.90 and 1.85) whereas highest diversity index value was observed in the premonsoon season (1.94) during first year of the study period, and for the second year, higher value was noted during the monsoon season (1.91). The Shannon-Weaver diversity index value for oligochaetes in P2 ranged from 1.97 to 2.05. The lowest Shannon-Weaver diversity index value in the first year of study was noted in the premonsoon season (1.97), and in the second year it was during the postmonsoon season (1.94). Highest $H^{\prime}$ value was noted during the monsoon season of the study period (2.03 and 2.05). In P3, Shannon-Weaver diversity index value ranges from 1.69-1.78. Lower diversity value (1.69 and 1.72) was noted in premonsoon season during the study period. Highest diversity value was noted during the monsoon season (1.78) in the first year while in the second year it was during the postmonsoon season (1.76). Shannon-Weaver diversity index value for oligochaetes was found lowest (1.69) in pond 3 during premonsoon season, and the highest diversity index value (2.05) was noted in pond 2 during monsoon season of the study period. 
TABLE 3: Shannon-Weaver diversity index $\left(H^{\prime}\right)$.

\begin{tabular}{lcccc}
\hline Period of study & Seasons & P1 & P2 & \\
\hline \multirow{2}{*}{$2006-2007$} & Postmonsoon & 1.90 & 2.00 & 1.73 \\
& Premonsoon & 1.94 & 1.97 & 1.72 \\
\hline \multirow{2}{*}{$2007-2008$} & Monsoon & 1.92 & 2.03 & 1.78 \\
& Postmonsoon & 1.85 & 1.97 & 1.98 \\
& Premonsoon & 1.89 & 2.05 & 1.69 \\
\hline
\end{tabular}

\section{Discussion}

Aquatic oligochaeta (Clitellata) has been universally applied on bioassessment assays as bioindicators to reflect the organic pollution in rivers and streams. Total numerical density of oligochaetes was higher in $\mathrm{P} 1\left(1400 \mathrm{No} / \mathrm{m}^{3}\right)$ during postmonsoon season, in the 1st year of study period. The average numerical density of total oligochaetes was 159 ind. $\mathrm{m}^{-3}$ for pond 1, comparatively higher density value with respect to P2 and P3. During the study, the most abundant genus was Dero sp., in the Naididae family. Among the Dero species, Dero digitata was identified in all the studied ponds. Dero digitata, Stylaria fossularis, Aulophorus furcatus, and Tubifex tubifex were identified in all the ponds.

During the first year (2006-2007) of the study period, the diversity values of oligochaetes were found to be high in monsoon season at P2 and P3 whereas in the second year (2007-2008) of the study period, the diversity values of oligochaetes in P1 and P2 were higher in the monsoon season. Shannon-Weaver diversity index values estimated show that in pond $1 H^{\prime}$ ranges from 1.85 to 1.94 , and in pond $2 H^{\prime}$ varies from 1.97 to 2.05 while in pond $3 H^{\prime}$ ranges from 1.69 to 1.78 .

Tubifex tubifex and Limnodrilus hoffmeisteri are the pollution-indicator oligochaete species identified in the fresh water ponds, which reveals that the studied ponds are subjected to pollution. Limnodrilus hoffmeisteri occurs in a wide variety of surface water habitats, reaching very high abundance in organically enriched areas often with Tubifex tubifex [20]. In the present study indicators of organic pollution, Limnodrilus hoffmeisteri and Tubifex tubifex were found together at P1 and P3. These species were found in the regions in which the organic pollution was high; the D.O. was too low. The numbers or proportion of specific species, such as Limnodrilus hoffmeisteri and Tubifex tubifex, are often used as symbolic indicators for organic pollution due to their dominant status in polluted areas $[1,21]$. In conditions of low dissolved oxygen concentrations prevalent in water bodies receiving heavy sewage pollution, Limnodrilus hoffmeisteri and Tubifex tubifex predominate and other species are eliminated in a rough sequence, dependent on the level of pollution. The respiratory physiology of some species is adapted to operate at very low oxygen concentrations and they are able to survive for long periods in anaerobic conditions. Slow moving water with weak current enables more pollution and more organic debris to accumulate, and the tubificids prefer such habitats [22].

Limnodrilus hoffmeisteri was identified in pond 1 and pond 3 only. Abundance of Limnodrilus hoffmeisteri was positively correlated to the degree of eutrophication due to its ability to tolerate low dissolved oxygen as the worms exhibit very marked physiological tolerance for oxygen depletion related to excess decomposable organic matter present in the environment, but they do decrease in number when conditions are at their worst. The reproductive rate of $L$. hoffmeisteri is also unaltered by decrease in dissolved oxygen to very low concentrations [21]. Limnodrilus hoffmeisteri, a cosmopolitan species occurring in a wide variety of surface water habitats, is perhaps the most ubiquitous and commonly collected freshwater tubificid worldwide, despite its sexual mode of reproduction [23].

In the distribution of oligochaete species the data related to the water quality are as important as the physical features of the micro habitats in which they live. The most important of these physical features are the existence of the type of bottom material, current rate, and the vegetation with the different features [24]. Similar studies on oligochaete community of Dal Lake, Kashmir, also show that the nature of the sediment influenced the population dynamics of the oligochaetes of the lake and the dominant oligochaetes of Dal Lake, Kashmir, include Limnodrilus hoffmeisteri, Tubifex tubifex, Branchiura sowerbyii, Aelosoma sp., and Nais sp. which thrive in sediments rich in organic nutrients [25].

\section{Conclusions}

In the present study, Shannon-Weaver diversity index value for oligochaetes in ponds was found to be the lowest during premonsoon season, and the highest diversity index value was noted during monsoon season of the study period. Naididae was the most diverse group identified, with six species and one genus; genus dero was represented by three species; Tubificidae was represented by two species belonging to two genera; Aeolosomatidae was represented by one genus. Dero digitata, Aulophorus furcatus, Stylaria fossularis, and Tubifex tubifex were present in all the studied ponds, but Aeolosoma sp. was present only in P2. The pollution-tolerant species Tubifex tubifex and Limnodrilus hoffmeisteri were identified in P1 and P3 and indicate the pollution of the ponds in Thiruvananthapuram district, Kerala, South India.

\section{Conflict of Interests}

The authors declare that there is no conflict of interests regarding the publication of this paper. 


\section{Acknowledgments}

The authors gratefully acknowledge Dr. Sheila Cherian, Retd. Lecturer (Selection grade), Department of Zoology, All Saints' College, Thiruvananthapuram, Kerala, India, for her valuable suggestions for the identification of oligochaetes for this study. Also they thank the Head Department of Environmental Sciences, University of Kerala, India, for providing laboratory facilities and support throughout the study.

\section{References}

[1] R. O. Brinkhurst and B. M. G. Jamieson, Aquatic Oligochaeta of the World, Oliver and Boyd, Edinburg, Tex, USA, 1971.

[2] C. F. Mason, Biology of Fresh Water Pollution, Longman Group Limited, Essex, UK, 1996.

[3] G. Milbrink, "On the use of indicator communities of Tubificidae and some Lumbriculidae in the assessment of water pollution in Swedish lakes," Zoon, vol. 1, pp. 125-139, 1973.

[4] G. R. Perez, Guide for the Study of Aquatic Macro Invertebrates, Antioquia, Editorial Presencia, Bogota, Colombia, 1988.

[5] J. Stephenson, The Oligochaeta, vol. 16, Clarendon Press, Oxford, UK, 1930.

[6] K. S. P. Aiyer, "An account of the oligochaeta of Travancore," Records of the Indian Museum, vol. 31, pp. 13-76, 1929.

[7] Y. Radhakrishna and K. Saibaba, "New record of fresh-water oligochaete, Aulophorus flabelliger Stephenson, 1930," Current Science, vol. 46, no. 16, pp. 564-565, 1977.

[8] B. SubbaRao, V. S. S. R. Rao, T. V. Ratnam, and A. C. S. Reddy, "Studies on salinity tolerance and preference of the tubificid oligochaete Monopylephorus waltairensis," Journal of the Marine Biological Association of India, vol. 21, no. 1, pp. 61-66, 1979.

[9] S. Sobhana and N. B. Nair, "Breeding frequency of Branchiura sowerbyi Beddard and Limnodrilus hoffmeisteri Claparede (Annelida, Oligochaeta, Tubificidae)," Comparitive Physiology and Ecology, vol. 9, no. 4, pp. 302-305, 1984.

[10] S. K. Battish and M. Sharma, "Freshwater oligochaetes with new records from India," Geobios New Reports, vol. 16, no. 1, pp. 8084, 1991

[11] S. K. Mukhopadhyay, "Oligochaeta," in State Fauna Series 3: Fauna of West Bengal, Part 10, pp. 95-123, Zoological Survey India, Kolkata, India, 1998.

[12] H. Nesemann, G. Sharma, and R. K. Sinha, "Aquatic Annelida (Polychaeta, Oligochaeta, Hirudinea) of the Ganga River and adjacent water bodies in Patna (India: Bihar), with description of a new leech species (Family Salifidae)," Annalen des Naturhistorischen Museums in Wien B, vol. 105, no. 1, pp. 139-187, 2004.

[13] K. V. Naidu, The Fauna of India and the Adjacent CountriesAquatic Oligochaeta, Zoological Survey of India, Kolkata, India, 2005.

[14] M. I. Naveed, "Preliminary studies on aquatic oligochaeta in and around Chennai, Tamil Nadu, India," Turkish Journal of Zoology, vol. 36, no. 1, pp. 25-37, 2012.

[15] R. G. Wetzel, Limnology, Saunders College Publishing, Washington, DC, USA, 2nd edition, 1983.

[16] P. S. Welch, Limnology, McGraw-Hill, New York, NY, USA, 1952.

[17] R. O. Brinkhurst, A Guide for the Identification of British Aquatic Oligochaetes, University of Toronto, Fresh Water Biological Assosciation, 1971.
[18] H. B. Ward and C. Whipple, Fresh Water Biology, John Wiley \& Sons, Chapman \& Hall, London, UK, 1918.

[19] C. E. Shannon and W. Weaver, The Mathematical Theory of Communication, University of Illinois press, Urbana, Ill, USA, 1949.

[20] R. O. Brinkhurst, "Oligochaeta," in Keys to the Water Quality Indicative Organisms of the South Eastern United States, F. K. Parrish, Ed., pp. 69-85, United States Environmental Protection Agency, Office of Research and Development, Environmental Monitoring and Support Laboratory, Cincinnati, Ohio, USA, 1975.

[21] R. J. Aston, “Tubificids and water quality: a review," Environmental Pollution, vol. 5, no. 1, pp. 1-10, 1973.

[22] S. Yildiz and S. Balik, "The oligochaeta (Annelida) fauna of Topçam Dam-Lake (Aydin, Turkey)," Turkish Journal of Zoology, vol. 30, no. 1, pp. 83-89, 2006.

[23] H. Swayne, M. Day, and M. J. Wetzel, "Limnodrilus hoffmeisteri (Annelida: Oligochaeta: Tubificidae) in Pop's Cave, Wisconsin, USA," The Journal of Cave and Karst Studies, vol. 66, no. 1, pp. 28-31, 2004.

[24] N. Kazanci and S. Girgin, "Distribution of oligochaeta species as bioindicators of organic pollution in Ankara Stream and their use in biomonitoring," Turkish Journal of Zoology, vol. 22, no. 1, pp. 83-87, 1998.

[25] M. F. Mir and A. R. Yousuf, "Oligochaete community of Dal lake," Kashmir Oriental Sciences, vol. 8, pp. 83-87, 2003. 

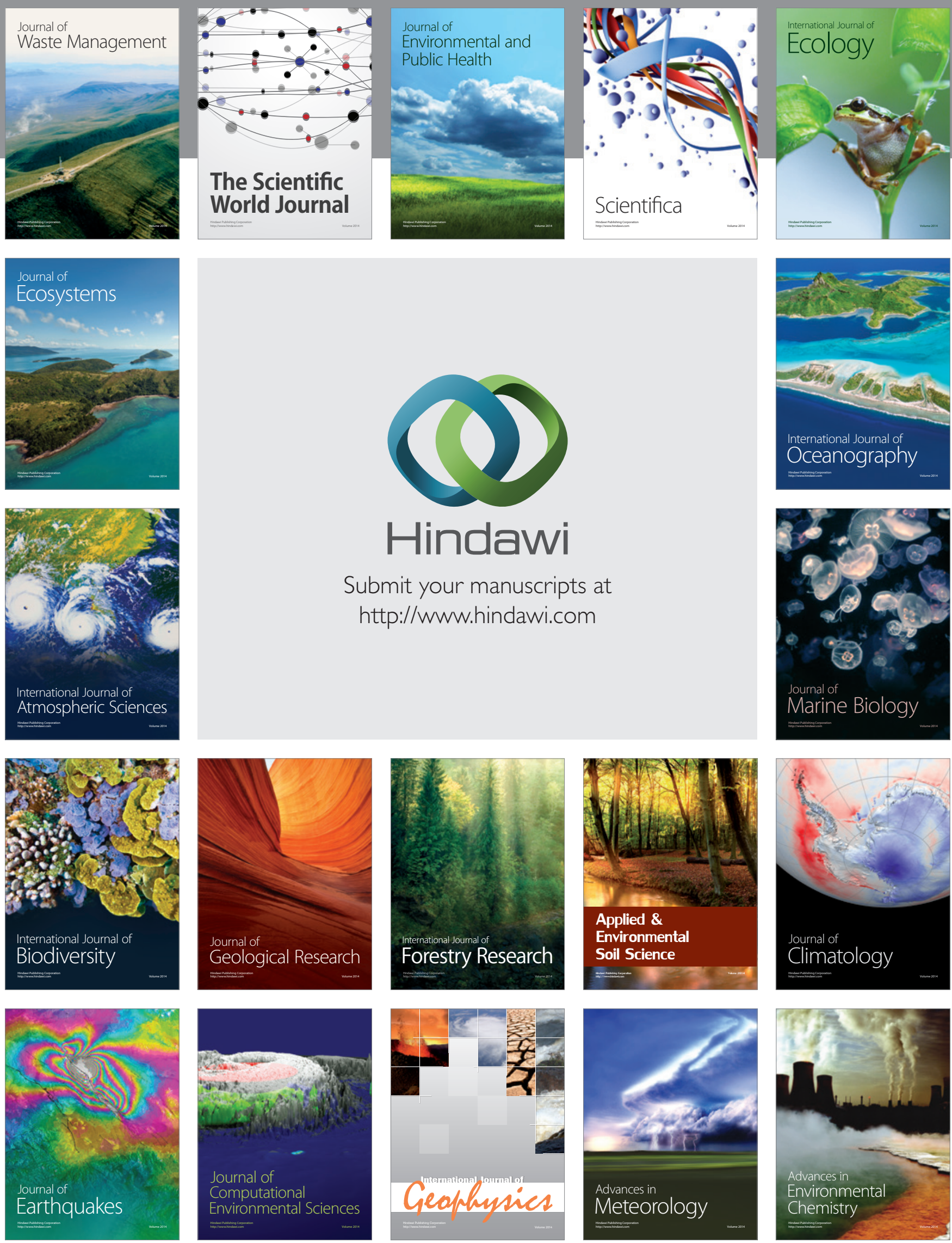